Jurnal Akuntansi dan Investasi, Vol. 19 No. 1, Hlm: 24-35 Januari 2018

Artikel ini tersedia di website: http://journal.umy.ac.id/index.php/ai

DOI: $10.18196 /$ jai.190189

\title{
Government Internal Control System Maturity: The Role of Internal Guidance and External Control of Local Government in Indonesia
}

Sutaryo* and Dedi Sinaga

Faculty of Economics and Business Universitas Sebelas Maret, Surakarta, Jawa Tengah, Indonesia

\begin{tabular}{l}
\hline A R T I C L E I N F O \\
\hline Article history: \\
received 5 May 2017 \\
reviwed 22 Jul 2017 \\
revised 02 Aug 2017 \\
accepted 08 Aug 2017
\end{tabular}

Keywords:

SPIP; Maturity;

Accountability; Internal

Control; External

Control; Characteristics

of Local Government

\begin{abstract}
A B S T RACT
This study discusses the Government Internal Control System (SPIP). The purpose of this study is to obtain empirical evidence of influence of guidance, external control, and the characteristics of Local Governments on Internal Control (SPIP) maturity of local governments in Indonesia. The samples used in this study are 188 local governments in 2014. The variables used include the dependent variable, i.e. the SPIP maturity of local government; Independent variables, i.e. guidance frequency, the number of internal control findings, total assets, total expenditure and the number of local government units. This study uses secondary data obtained from the Financial and Development Supervisory Agency (BPKP) and the Supreme Audit Agency (BPK). This study uses multiple regression analysis and the results show that the guidace frequency and total expenditure have a positive influence on maturity of SPIP, SPI finding has a negative influence, and the total assets and the number of units do not have significant influence on the maturity of SPIP.
\end{abstract}

(C)2018 JAI. All rights reserved

\section{INTRODUCTION}

Transparency and accountability in state financial management are the main goals of government financial accountability report. In the effort of improving the transparency, accounttability, and performance of this state financial management, a system capable of adequate confidence that the activities in government agencies have been performed effectively, efficiently, and reported reliably. This system is known as Government Internal Control System or Sistem Internal control Pemerintah (hence SPIP) which is organized at the government administrations thoroughly (Law Number 1 year 2004 concerning State Treasury).

The implementation of Government Internal Control Systeman (SPIP) in Indonesia began when Government Regulation (GR) Number 60 year 2008 was issued. This Government Regulation is a part of the reform in finance field in Indonesia aiming at improving the state financial management where prior to the issuances of three packages of state financial law, the state financial management used to use the system inherited from the Dutch collonial era (Simanjuntak, 2005).

An internal control system is built to be a tool to improve the reliability in reporting, operation effectiveness and efficiency, and compliance with the applicable laws and regulations (COSO, 2013). Coram et al. (2008) explain that any organization owning an internal audit function will be more capable of detecting accounting fraud.

Building an effective internal control system has been the main issue since many fraud cases are found due to the weak internal control system (Minelli et al., 2009). Framework COSO (2013) suggests that a relatively internal control can give some assurance that the company performs their operation efficiently and is on the right track towards their predetermined goals, their financial management and reporting data are reliable, and promotes compliance with applicable laws and regulations.

An assessment of internal control system is highly required to figure out whether the implemented SPI has been running effectively or not. It is hard to determine the accurate quantitative measurement of internal control (Zhou et al., 2016). The structure of internal control effect- 
tiveness can explained theoretically, yet it is not that easy to measure (Agbejule and Jokipii, 2009). Clements et al. (2015) mention that any improvement in internal control effectiveness can be measured by the decreased number of reported internal weaknesses. Ashbaugh-Skaife et al. (2007) find that the improvement of internal control effectiveness is related to improved profit quality. Zhou et al. (2016) state that internal control can improve a company's performance. Any internal control which has moved towards its maturity stage will be more effective as compared to when it is introduced and implemented.

One method of measuring the success or, in other word, effectiveness of an internal control is maturity model. Maturity model is a systematic measurement which can describe and explain the components of a process believed to move towards better outputs and outcomes. The low maturity level implies the low success probability in achieving the goals and the higher maturity level implies higher possibility of success (IIA, 2013).

Assessment of SPIP using maturity model has been done by Financial and Development Supervisory Board or Badan Pengawasan Keuangan dan Pembangunan (BPKP). Until October 2016, the assessment of SPIP maturity has been done to 258 local governments. The results find that four local governments are still at maturity level 0, 136 local governments are at level 1, 109 local governments are at level 2, and nine local government are at level 3. This shows that most of the SPIP implementation maturity levels in Local Governments are at their "Initiated" and "Developing" stages.

The low SPIP maturity level indicates the low possibility of goal achievement (IIA, 2013). It is safe to say that this is consistent with the internal control findings based on the audit results of Supreme Audit Agency or Badan Pemeriksa Keuangan (BPK). BPK's audit results of Local Government Financial Statements or Laporan Keuangan Pemerintah Daerah (LKPD) in 2014 indicated that the number of findings related to SPI is till high, i.e. 6,452 findings (IHPS I and II in 2015).

BPK's audit results will be used by the government as a basis to make some necessary corrections and adjustments. The government is given a chance to respond to the findings and conclusions elaborated in the audit result report (Law Number 15 Year 2004). This way, BPK's findings related to SPI are expected to improve the effectiveness of SPIP execution in Local Governments.

Since Government Regulation Number 60 Year 2008 is issued, BPKP has been appointed as the advisor of SPIPs who are responsible for technical guidelines drafting, dissemination, education and training, SPIP guidance and counseling, and APIP competence improvement. Its appointment as the advisor is intended to strengthen and support the effectiveness of SPIP.

The SPIP guidance given by BPKP to local governments, where BPKP is actually not part of the organizational structure of any local government, can also be called as internal audit outsource. Internal audit outsource helps and cooperates with internal audit in solving several problems. For example, an organization asks an external service provider to help the management define audit risks. One reason why internal audit outsorce is required is because of the ineffective internal audit function. In addition, some advantages can be obtained from internal audit outsource, i.e. it is independent, cost-effective, flexible, and of assured quality (Carey and Subramaniam, 2006).

Such a condition gives an opportunity to develop a study which can provide some description on SPIP maturity, and how BPK's internal control findings and SPIP guidance influence it. There is only a few research on SPI maturity in Indonesia, particularly in public sector, has been conducted since assessment of SPIP maturity in Indonesia is relatively new. Since Government Regulation Number 60 year 2008 was issued, the government's focus was on the implementation of SPIP, rather than on assessing the maturity. The guideline for assessing and strategy of improving SPIP maturity has recently been used, formally, since March 2016 (Regulation of BPKP Chief Number 4 Year 2016).

Studies on the effectiveness of internal control have been done by several researchers. Xu and Gao (2015) studied the factors influencing internal control effectiveness using Corporate Governance perspective. Meanwhile, Khlif and Samaha (2016) studied the influence of audit committee activity and external auditor measurement on internal control quality. Agbejule and Jokipii (2009) studied how different strategy orientations can influence internal control effectiveness. Finally, Doyle et al. (2007), Zhang et al. (2009), and Ashbaugh-Skaife et al. (2007) studied how the influence of organizational characteristics on internal control was. For local context of Indonesia, 
Zaelani and Martani (2011) studied the influence of local government characteristics in Indonesia on internal control using internal control findings as the measurement of internal control weaknesses.

This study uses SPIP maturity as a more comprehensive measurement of internal control effectiveness than internal control findings. The SPIP maturity measurement is performed systematically so that it can describe and explain the components of internal control processes believed to move towards better outputs and outcomes. In addition, this research will also take a look at how the characteristics of local governments influences the maturity of SPIP which has been implemented. The local government characteristics used in this research consists of the amount of expenditure realization, total assets, type, and number of local administration's working units (SKPD) owned by each local government. The results of this research can contribute to, i.e. adding and strengthening, the references particularly in relation to internal control in the government, especially in regard to SPIP maturity. In addition, this research also contributes to the information used for passing government policies in their efforts of improving the local government's SPIP maturity related to those factors influencing them, so that the government as a regulator can make a more tested formula in passing policies to improve SPIP maturity in the effort of making the local financial management more transparent and accountable.

\section{LITERATURE REVIEW AND HYPOTHESIS DEVELOPMENT}

\section{Theory of Agency in Public Sector}

Agency relationship is defined as a contract where one or more persons (principal) hire others (agents) to perform some services for their sake by delegating some authorities of making decisions to these agents (Jensen and Meckling, 1976). Halim and Abdullah (2006) suggest that the principalagent theory analyzes the contractual structure between two or more individuals, groups, or organizations. One party (principal) makes a contract, either implicitly or explicitly, with other parties (agents) expecting that the agents will take some actions/do some jobs as the prinsipal wish them to (in this case authorization). Thereby, agency relationship can occur in any entity which applies contractual structure in their operations.

From the perspective of formal rules in public sector, the governmental entities are run in reference to a set of regulations specifying the duties, authorities, and responsibilities of each participant. Despite the differences in the procedure and mechanism of interparticipant relationships in a governmental organization from those in corporation sector, the very existence of formal bond shows that there is a contract in the governmental organizations in Indonesia. This justifies the presence of agency relationship in governmental organizations in Indonesia (Sutaryo \& Jakawinarna, 2013).

Lupia and McCubbins (2000) in Halim and Abdullah (2006) state that in modern democracy, there are at least four characteristics of delegation, namely: (1) the presence of principal and agents, (2) possibility of conflict of interest, (3) asymmetric information, and (4) possibility that principal can reduce agency problems.

The effort of dealing with or reducing this agency problems will create agency cost which will be borne by both the principal and the agents. Jensen and Meckling (1976) divide this agency cost into monitoring cost, bonding cost and residual loss. Monitoring cost is the cost arising out and borne by the principal to monitor the agent's behavior, i.e. to measure, observe, and control their behaviors. Bonding cost is the cost borne by the agent to establish and comply with a mechanism which ensures that the agent will take actions for the principal's best interest. Furthermore, residual loss is the sacrifice in the form of reduced prosperity of the principal as a result of differences between agent's decisions and principal's decisions. One of the manifestations of this agency cost is the implementation of internal control system. An internal control system can reduce the possibility of conflict of interest and asymmetric information which can harm the principal.

\section{Government Internal Control System Maturity}

Government Internal Control System is an integral process to the actions and activities continuously performed by leaders and all employees to give adequate confidence that the organization's goals will be achieved through effective and efficient activities, financial reporting reliability, state asset security and compliance with the regulations of law applied in the Government 
Institutions (GR Number 60 Year 2008). One method to measure the effectiveness of internal control is maturity model. According to IIA (2013), maturity model is a systematic measurement which can describe and explain the components of a process believed to move towards better outputs and outcomes. Andersen and Jessen (2003) suggest that the concept of maturity in an organization aims at directing the organization to reach their goals optimally.

To assess the effectiveness of SPIP execution, some indicators, approaches, and techniques need to be established. The appropriate indicators should be chosen to enable a good assessment of SPIP effectiveness. The reliability attributes of internal control are adapted to be the indicators of SPIP execution maturity.

The Government Internal Control System (SPIP) execution maturity level depicts the rank or structure of SPIP execution maturity with different characteristics from one level to another level. The low maturity level implies the low success probability in reaching the goals, and the higher maturity level implies the higher possibility of success (IIA, 2013).

The SPIP maturity framework has six levels, namely: "Absent", "Initiated", "Developing", "Defined", "Managed and Measured", "Optimum”. These levels are equal to levels $0,1,2,3,4$ and 5 respectively. Each maturity level has basic characteristics which shows the role or capability of SPIP execution in supporting the achievement of government institution's goals.

SPIP execution maturity level is a working framework containing the basic characteristics which show a structured and sustainable SPIP execution maturity level. This maturity level can be used at leas as an instrument for evaluating the SPIP execution, and generic guidelines to improve the maturity of internal control system.

Ever SPIP maturity level has its own basic characteristics which can significantly differs one level from the other, even due to sustainable process might intersect one another. These basic characteristics are visible from the general characteristics of each level as can be seen in Table 1.

\section{Guidance of SPIP Execution}

The guidance of SPIP execution is directly related to the internal monitoring mission on the accountability of financial and development management in order to manifest a clean and effective government and corporate governance (BPKP, 2016). The guidance of SPIP execution in

Table 1. SPIP Maturity Level

\begin{tabular}{|c|c|}
\hline Level & Characteristics \\
\hline Absent & $\begin{array}{l}\text { Ministry/Institution/Local Government has not at all had any policies and procedures } \\
\text { required to perform the internal control practices. }\end{array}$ \\
\hline Initiated & $\begin{array}{l}\text { There is an internal control practice, yet the risk and control approaches required are still in } \\
\text { its ad-hoc shape and unorganized well, without any communication and monitoring resulting } \\
\text { in the weaknesses being unidentified. }\end{array}$ \\
\hline Developing & $\begin{array}{l}\text { Ministry/Institution/Local Government has implemented the internal control practice, yet it is } \\
\text { not documented well and its implementation is highly dependent on individuals and has not } \\
\text { involved all units of the organization. The control effectiveness has not been evaluated, } \\
\text { allowing many weaknesses to have not been dealt with adequately. }\end{array}$ \\
\hline Defined & $\begin{array}{l}\text { Ministry/Institution/Local Government has implemented internal control practice and it is } \\
\text { well-documented. Yet, the evaluation of such internal control is done with no adequate } \\
\text { documentations. }\end{array}$ \\
\hline $\begin{array}{l}\text { Managed and } \\
\text { Measured }\end{array}$ & $\begin{array}{l}\text { Ministry/Institution/Local Government has implemented internal control effectively, with } \\
\text { each activity executing personnel keeping themselves in control of the activity towards the } \\
\text { achievement of that activity's goals as well as the Ministry/Institution/Local Government's } \\
\text { goals. The evaluation is performed formally and well-documented. }\end{array}$ \\
\hline Optimal & $\begin{array}{l}\text { Ministry/Institution/Local Government has implemented sustainable internal control, } \\
\text { integrated in their activity performance and supported by automatic monitoring using } \\
\text { computer application. }\end{array}$ \\
\hline
\end{tabular}

Source: Decision of BPKP Chief No. 4 Year 2016 on Guidelines for Assessment of and Strategy to Improve SPIP Maturity 
Table 2. SPIP Implementation Stage

\begin{tabular}{|c|c|}
\hline Stages & Description \\
\hline $\begin{array}{l}\text { Understanding and developing } \\
\text { common perception/ } \\
\text { Dissemination }\end{array}$ & $\begin{array}{l}\text { Building awareness of the importance of SPIP and building commitment to } \\
\text { implement SPIP }\end{array}$ \\
\hline Mapping/Diagnostic & Assessment of the existing system to find areas of improvement. \\
\hline Infrastructure Development & Constructing infrastructure to implement SPIP elements \\
\hline Internalization & $\begin{array}{l}\text { Internalizing the infrastructure of SPIP elements into the orga-nization's real } \\
\text { activities }\end{array}$ \\
\hline Continuous Development & $\begin{array}{l}\text { Monitoring, evaluation, and development of SPIP to keep it func-tioning } \\
\text { effectively }\end{array}$ \\
\hline
\end{tabular}

Local Governments is performed by BPKP by drafting a technical guidelines for SPIP execution, SPIP dissemination, SPIP education and training, SPIP guidance and counseling, and APIP competence improvement. The initial stage of SPIP execution in Local Government begins with implementation stages. These implementation stages consist of as can be seen in Table 2 (BPKP, 2009).

In 2015-2019 period, the guidance of SPIP execution is directed towards improvement of SPIP maturity at Local Government level, and even up to national development (RPJMN 20152019) program level (priority). The Local Government's SPIP execution does not fall under the responsibility of BPKP, rather each Local Government shall be held responsible for it respectively. BPKP as the advisor of SPIP execution can merely improve the guidance quality by performing their tasks of drafting SPIP guidelines and training, safeguarding the implementation of all SPIP elements throughout the main activities and management actions of the Local Governments.

This is done by making risk introduction and control a culture by all personnel and leaders in the execution of their main activities as specified in the policies and standard operating procedures (SOP) of activity performance. Regular communication and evaluation of the consistency between policies and performance of activities according to SOP are expected to make the personnel and leaders aware of the government goal achievement and development, which, in turn, will improve the overall maturity of SPIP implementation in Local Governments (BPKP, 2016).

\section{External Control}

External control is a form of supervision done by a supervisory unit from completely outside the executive organization environment
(Baswir, 1999 in Halidayati, 2014). External control is performed by the House of Representative or Dewan Perwakilan Rakyat (DPR), Supreme Audit Agency (BPK) and directly by the people.

BPK as an external supervisor in delivering their opinion of the Local Government's Financial Statements, also conveys the findings related to SPI execution within the local government environment. Internal control is a process designed to give some feasible certainty regarding the achievement of management's goals on their financial reporting reliability, operation effectiveness and efficiency, and compliance with applicable laws and regulations (Arens et al., 2006). Framework COSO states that a fairly effective internal control can provide assurance that the company runs their operation efficiently and consistent with the predetermined goals, reliable financial reporting and management data, and promotes compliance with applicable laws and regulations. The public auditor agency of the United States of America, through SAS (Statements on Auditing Standards), uses internal control as one variable required to be audited in detecting any corruption.

\section{Characteristics of Local Government}

Different characteristics of each organization can influence the effectiveness of internal control. Doyle et al. (2007) study the determinant factors of internal control weaknesses in 779 companies and found that smaller, younger companies with weaker financial condition, or being restructuring process tended to have more internal control weaknesses.

Zhang et al. (2009) conducted research on internal control effectiveness in companies in China. They found that the internal control quality was positively related to the company's size and financial condition. The company's size was 
proxied with the company's total asset value, and their financial condition was proxied with ROE (Return on Equity) value.

Marfiana and Kurniasih (2013) study the influence of local government characteristics on financial performance. The characteristics of local government under study are proxied by the total assets, portion of locally generated recurring revenues to total revenues, portion of general allocation fund to total revenues, total local expenditures, and number of legislative members. Based on the research results, it is found that the dependence level on central government and total local expenditures have significant influence on local government's financial performance.

Another research conducted by AshbaughSkife et al. (2007) find that the companies reporting their internal control weaknesses have more complex operations. The company's complexity is proxied with the number of business segments, sales in foreign currency, and number of supply.

In relation to the achievement of government institution's goals, the capacity of SPIP execution is influenced by the complexity of government institution's activities. Consistent with the definition of SPIP, i.e. an integral process to actions and activities, the wider the scope or the more complex the activity operation processes in the $\mathrm{K} / \mathrm{L} / \mathrm{P}$ organization, the higher the control system capability is required to be.

\section{Hypothesis}

Coram et al. (2008) study the role of internal audit in detecting frauds and find that the combination between internal audit insource and outsource can be more effective in detecting fraud as compared to merely either internal audit insource or internal audit outsource.

The guidance of SPIP execution in Local Governments is done by BPKP by drafting technical guidelines of SPIP execution, SPIP dissemination, SPIP education and training, SPIP guidance and counseling, and APIP competence improvement. This role, conceptually, matches the internal audit outsource concept, i.e. the role of assisting and cooperating with internal audit (insource) in dealing with some problems in the organization (Carey and Subramaniam, 2006). This guidance is intended for SPIP in local governments to run effectively and efficiently. The more frequently the SPIP guidance is given, the more weaknesses will be found and the more remedies will be made to improve SPIP quality.

$\mathrm{H}_{1}$ : SPIP guidance has positive influence on SPIP maturity.

Most studies on internal control effectiveness use the number of internal control findings as their proxy. Clements et al. (2015) suggest that the improvement in internal control effectiveness can be measured through the decreased number of internal weaknesses being reported. Zaelani and Martani (2011) study the internal control effectiveness in local governments in Indonesia and use the number of internal control findings obtained from LKPD previously audited by BPK as their proxy for internal control effectiveness. In the delivery of internal control findings by BPK to the local governments, also delivered are the recommendations related to these findings. Local governments are given chances to follow-up the recommendations for such internal control findings by making some remedies. In other words, when the remedy recommendations are followed-up by the local governments, it will then improve the internal control effectiveness the following year. Thus, the more internal control findings are reported by BPK, the more remedies can be made to improve the SPIP maturity.

$\mathrm{H}_{2}$ : The number of internal control findings has positive influence on SPIP maturity.

The research by Doyle et al. (2007) and Zhang et al. (2009) find that the size of a company has positive influence on internal control quality. The greater the size of a company, the less internal control weaknesses would be found. In other words, the control quality will be better. Greatersized organizations have more standard procedures in their financial reporting and have more human resources for separating tasks which are organized well.

In addition, regions of greater size or with greater total assets will have great demand in reporting their mandatory disclosure to the public. Local governments need to disclose further the list of assets they own, their maintenance and management (Suhardjanto and Yulianingtyas, 2011). Therefore, the greater the size of a local government as projected by the total assets they own, the better their SPIP maturity would be.

$\mathrm{H}_{3}$ : Total assets has positive influence on SPIP maturity. 
One of SPIP functions is to improve the performance of state financial management (GR 60) Year 2008). The results of Marfiana and Kurniasih's (2013) research show that the total local expenditures have positive influence on local government's performance. Local expenditures are used to maintain and improve the quality of people's life which is embodied in the improved service of mandatory services and other servies in such fields as education, healh, social facility provision, general facility, and social security system development. Hence, the greater the total local expenditures, the greater the fund allocated for improving SPIP maturity.

$\mathrm{H}_{4}$ : Total local expenditure has positive influence on SPIP maturity.

Ashbaugh-Skife et al. (2007) find that the company reporting internal control weaknesses has more complex operations. This company's complexity is proxied, among other things, with the number of business segments. Furthermore, Kumar and Kuldip (2016) also find the positive influence of firm size on performance and productivity. The organization complexity of local governments can be projected with the number of SKPDs they own. The more SKPDs the local governments own, the more problems they should deal with which may reduce SPIP maturity.

$\mathrm{H}_{5}$ : Number of SKPDs has negative influence on SPIP maturity.

\section{RESEARCH METHOD}

\section{Population, Sample, and Sampling Technique}

The population in this research is all regency/municipality governments in Indonesia in 2014. The sample used in this research is taken using purposive sampling technique with the criteria of research sample in this study being formulated as follows in Table 3 . There are 508 local governments in Indonesia which consist of regencies and municipalities in 2014. Out of these 508 local governments in 2014, 38 neither submit any LKPD nor receive any audit from BPK. The SPIP maturity of 240 local governments is not assessed in 2014. From the remaining 230 governments, 42 local governments do not receive any SPIP guidance. Hence, the final number of samples used for data testing is 188 local governments.

\section{Data and Source of data}

The data of this research are secondary ones, i.e. in reference to the information collected by individuals other than the researchers conducting this research (Sekaran and Bougie, 2013). The data and its source are shown in Table 4.

\section{Variable and Variable Measurement}

This research uses dependent variable in the form of Local Government's SPIP maturity and independent variables consisting of: SPIP guidance made by BPKP; number of SPI weaknesses from BPK's financial audit; and characteristics of local government consisting of total assets, total expenditures, and number of SKPDs of the local government. Additionally, italso uses control variable in the form of type of local governments. The variables and their measurements are presented in detail in the following table.

\section{Research Model}

The model used to test the hypotheses in this research is multiple regression model with the following formula:

$$
\begin{aligned}
\text { MSPIP }= & \beta_{0}+\beta_{1} \text { LnFSPIP }+\beta_{2} \text { LnTSPI }+ \\
& \beta_{3} \text { LnTASET }+\beta_{4} \text { LnBLJ }+\beta_{5} \text { LnSKPD }+ \\
& \beta_{6} \text { TIPE }+\mathrm{e} i
\end{aligned}
$$

Note:

MSPIP : SPIP maturity;

$\beta 1, \beta 2, \beta_{3}, \ldots, \beta 6$ : Regression Coefficient;

LnFSPIP : :SPIP guidance frequency;

LnTSPI : Internal control findings;

LnTASET : Local government's total assets;

LnBLJ : Local government's total expenditures;

LnSKPD : Number of SKPDs;

TIPE : Type of local government;

e $\quad$ : standard error 
Table 3. Result of Data Sample Selection

\begin{tabular}{clc}
\hline No. & \multicolumn{1}{c}{ Description } & Total \\
\hline 1 & Local Governments in Indonesia (regencies and municipalities) & 508 \\
2 & Local Governments which do not submit LKPDs in 2014 and are not audited by BPK & -38 \\
& $\begin{array}{l}\text { in 2015 } \\
3\end{array}$ & Local Governments against which no SPIP maturity assessments are conducted until \\
& $\begin{array}{l}2016 \\
4\end{array}$ & -240 \\
& Local Governments which to which no SPIP guidance is given until 2014 & -42 \\
\hline
\end{tabular}

Table 4. Data and Source of Data

\begin{tabular}{lll}
\hline No. & Data & Source of Data \\
\hline 1. & $\begin{array}{l}\text { Audited 2014 Local Government's Financial } \\
\text { Statements. }\end{array}$ & $\begin{array}{l}\text { Center for Information and Communication of } \\
\text { BPK RI }\end{array}$ \\
2. & $\begin{array}{l}\text { List of local governments receiving guidance } \\
\text { from BPKP }\end{array}$ & $\begin{array}{l}\text { Planning and Supervision Bureau of BPKP } \\
\text { 3. }\end{array}$ \\
Score of Local Government's SPIP maturity & PKD Monitoring Director of Area 2 \\
\hline
\end{tabular}

Table 5. Research Variable

\begin{tabular}{|c|c|c|c|}
\hline No. & Variable & Variable Type & Operational Definition \\
\hline 1. & SPIP maturity & dependent & $\begin{array}{l}\text { Score of SPIP maturity from the results of } \\
\text { assessment made by BPKP at } 0.00 \text { to } 5.00 \text { score } \\
\text { interval }\end{array}$ \\
\hline 2. & SPIP guidance & independent & $\begin{array}{l}\text { Frequence of SPIP guidance given by BPKP during } \\
2014\end{array}$ \\
\hline 3. & $\begin{array}{l}\text { Internal control } \\
\text { findings }\end{array}$ & independent & $\begin{array}{l}\text { Number of cases of SPI weakness findings in the } \\
\text { result report of audit of Local Government's } \\
\text { Financial Statements }\end{array}$ \\
\hline 4. & Total assets & independent & Local government's total assets specified in LKPDs. \\
\hline 5. & Total expenditures & independent & $\begin{array}{l}\text { Local government's total expenditures specified in } \\
\text { LKPDs. }\end{array}$ \\
\hline 6. & Number of SKPDs & independent & Number of SKPDs owned by local govern-ments. \\
\hline
\end{tabular}

Table 6. Descriptive Statistic $(\mathrm{n}=188)$

\begin{tabular}{ccccc}
\hline Variable & Mean & Std. Dev. & Min & Max \\
\hline MSPIP & 1,9314 & 0,54806 & 0,26 & 3,56 \\
FSPIP & 3,2872 & 2,80992 & 1,00 & 16,00 \\
TSPI & 11,3511 & 5,17957 & 1,00 & 31,00 \\
BLJ & $1,2884 \mathrm{E} 6$ & $8,45716 \mathrm{E} 5$ & $3,78 \mathrm{E} 5$ & $6,44 \mathrm{E} 6$ \\
TASET & $3,2309 \mathrm{E} 6$ & $2,90172 \mathrm{E} 6$ & $7,14 \mathrm{E} 5$ & $2,34 \mathrm{E} 7$ \\
SKPD & 55,6277 & 26,17669 & 25,00 & 196,00 \\
TIPE & 0,2234 & 0,41764 & 0,00 & 1,00 \\
\hline
\end{tabular}

Note: MSPIP (SPIP Maturity), FSPIP (SPIP Guidance), TSPI (Internal Control Findings), BLJ (Local Government's Total Expenditures), TASET (Total Assets), SKPD (Number of SKPDs), TIPE (Type of Local Government)

\section{RESULTS AND DISCUSSION}

\section{Descriptive Statistics}

The descriptive statistic testing in this research is intended to provide a description about the distribution of variable frequency in research. The descriptive statistic of each variable in this research is presented in Table 6.

\section{Classical Assumption Test}

The stages on multiple regression testing uses several classical assumption tests which should be fulfilled, including: normality test, multicollinearity test and heteroscedasticity test which are shown in detail in Table 7 . It can be seen that from the normality test results it is found that the data are normally distributed and from the results of classical assumption testing which consists of 
autocorrelation, heteroscedasticity and multicollinearity it is found that the data are free from these classical assumptions. Thus, the research hypothesis testing using regression equation can be performed.

\section{Hypothesis Testing Results}

The results of data analysis using multiple regression model in this research are presented in Table 8. It can be observed that the $\mathbf{F}$ value is 6.869 at a significance rate of 0.000 . The results are below the significance rate of $5 \%$, hence the multiple regression model in this research is feasible for its use in hypothesis testing. The
Adjusted R Square value is 0.158 . This shows that the independent variables in the regression testing model in this research can explain the influence on SPIP maturity (MSPIP) by $15.8 \%$, and the remaining $84.2 \%$ is explained by other factors beyond the model.

Table 8 shows that LN_FSPIP variable, i.e. the SPIP guidance has a coefficient value of 0.320 at sig. value of 0.003 . Therefore, $\mathrm{H} 1$ is confirmed. This indicates that SPIP guidance variable has positive influence on SPIP maturity. This also indicate that the more frequent SPIP guidance is given, the better the local government's SPIP quality would be. The guidance plays a role in producing remedies to the implemented SPIP.

Table 7. Classical Assumption Testing Results

\begin{tabular}{|c|c|c|c|c|c|}
\hline Test & $\mathbf{N}$ & K-S Z & Tolerance & VIF & Sig. \\
\hline Normality & 188 & 0,451 & & & 0,987 \\
\hline Autocorrelation & 188 & & & & 0,079 \\
\hline Heterocedasticity & 188 & & & & \\
\hline - LN_FSPIP & & & & & 0,119 \\
\hline - LN_TSPI & & & & & 0,056 \\
\hline - $\quad$ LN_BLJ & & & & & 0,438 \\
\hline - LN_TASET & & & & & 0,152 \\
\hline - $\quad$ SKPD & & & & & 0,372 \\
\hline - TIPE & & & & & 0,559 \\
\hline \multicolumn{6}{|l|}{ Multicollinearity } \\
\hline - LN_FSPIP & & & 0,828 & 1,208 & \\
\hline - LN_TSPI & & & 0,994 & 1,059 & \\
\hline - LN_TASET & & & 0,223 & 4,477 & \\
\hline - LN_BLJ & & & 0,234 & 4,281 & \\
\hline$-\quad$ SKPD & & & 0,938 & 1,066 & \\
\hline - $\quad$ TIPE & & & 0,886 & 1,128 & \\
\hline
\end{tabular}

Note: MSPIP (SPIP Maturity), FSPIP (SPIP Guidance), TSPI (Internal Control Findings), BLJ (Local Government's Total Expenditures), TASET (Total Assets), SKPD (Number of SKPDs), TIPE (Type of Local Government), N = Number of Samples, K-S Z = Kolmogorov-Smirnov Z,VIF= Variance Inflation Factor.

Table 8. Hypothesis Testing Results

\begin{tabular}{lcccl}
\hline & Expt & B & t-value & Sig. \\
\hline Constant & & 0,320 & 0,298 & 0,766 \\
LN_FSPIP & $(+)$ & 0,171 & 3,043 & $0,003^{*}$ \\
LN_TSPI & $(+)$ & $-0,162$ & $-2,130$ & $0,035^{*}$ \\
LN_BLJ & $(+)$ & 0,319 & 2,136 & $0,034^{*}$ \\
LN_TASET & $(+)$ & $-0,169$ & $-1,430$ & 0,155 \\
LN_SKPD & $(-)$ & $-0,050$ & $-0,472$ & 0,637 \\
TIPE & $(+)$ & 0,451 & 1,278 & 0,187 \\
R $^{2}$ & & & 0,185 & \\
Adj. R & & & 0,158 & \\
F-Value & & & 0,869 & \\
Asymp sig. & & & 0,000 & \\
\hline Note: FSPIP & (SPIP Guidance), TSPI (Internal Control Findings), BLJ (Local Government's Total \\
Expenditures), TASET (Total Assets), SKPD (Number of SKPDs), TIPE (Type of Local Government), \\
${ }^{*}$ significant at alpha level 5\%
\end{tabular}


The remedy is performed when weaknesses which can reduce the SPIP maturity value are found. This result confirms the result from Coram et al. (2006) which find that the combination between internal audit insource and outsource can be more effective in detecting fraud as compared to merely either internal audit insource or internal audit outsource.

The internal control findings variable (LN_TSPI) shows a sig. value of 0.035 , yet the coefficient value is -0.162 . Hence, internal control findings has negative influence on SPIP maturity and the second hypothesis is rejected. This research uses dependent variable data, internal control findings, and variable independent, SPIP maturity, from different periods. The data on SPIP maturity used in this research are taken from a period after the internal control findings data. Internal control findings which has negative influence on SPIP maturity is possibly because the local governments have not completely followedup the recommendations given by BPK in relation to these findings. When the follow-ups of BPK's recommendations have not been completely finished, then the remedies to the internal control findings have not been completely done. Such a condition indicates that the local government APIP has not had enough capability in following up BPK's audit findings. It is proven by the low level of local government APIP. The local government IACM APIP on average is at level 1 or 2 , meaning they can only supervise and cannot take initiatives for prevention and remedy.

The total assets (LN_TASET) variable has a coefficient value of -0.169 at a sig. value of 0.155 . This result shows that the total assets variable has no influence on SPIP maturity. Therefore, the third hypothesis is not proven. This research does not confirm the hypothesis built by the researcher, i.e. the higher the total assets of a local government, which is a projection of its size, the greater the capability that the local government will have in developing SPIP to be developed. Marfiana and Kurniasih (2013) also find that total assets have no influence on the performance of local governments. The greatest composition of local government's assets is fixed assets. Meanwhile, the management of local government's fixed assets still experiences many problems. Thus, local governments fail to use these great resources to improve their SPIP maturity.

The local government's total expenditures (LN_BLJ) variable has a coefficient value of 0.319 at a sig. value of 0.034 . This result indicates that the expenditure variable has positive influence on SPIP maturity. Therefore, the fourth hypothesis is confirmed. Marfiana and Kurniasih (2013) also find that total expenditures of a local government have positive influence on the performance of that local government. It indicates that the local government's budget for local expenditure has been realized for improving the performance towards a better one. Pratama et al. (2015) also find that local expenditure has positive influence on Local Government's Financial Statements. It can then be concluded that the higher the total local expenditure, the higher the possibility of fund allocation used to improve SPIP maturity, hence the main goals of SPIP implementation can be reached, i.e. accountability and transparency in state financial management.

The local government's number of SKPDs (LN_SKPD) variable has a coefficient value of 0.050 at a sig. value of 0.637 . This result shows that the number of SKPDs variable has no influence on SPIP maturity. Therefore, the fifth hypothesis is rejected. Zaelani and Martani (2011) also find that complexity does not influence the effectiveness of SPI. The local government with large number of SKPDs is not necessarily more complex because SKPDs are established to manage such governmental affairs as finance, planning, supervision and technical issues of implementation. Hence, large number of SKPDs can indicate that the local government affairs are divided into this large number of SKPDs, and these SKPDs have their own affairs to deal with which are relatively equal among them. Meanwhile, as for the TYPE which is the control variable, the result shows that TYPE has no influence on the local government's SPI effectiveness. Thus, the type difference between municipality government and regency government does not become the factor which influence the SPI effectiveness of local governments in Indonesia.

\section{CONCLUSION}

This research is conducted to discover the influence of SPIP guidance and external control on government internal control system (SPIP) maturity of local governments in Indonesia. The results of hypothesis testing show that guidance frequency and total expenditures variables have positive influence on Local Government's SPIP maturity. Meanwhile, the internal control findings variable has negative influence on Local Govern- 
ment's SPIP maturity. The total assets and number of SKPDs variables have no influence on Local Government's SPIP maturity. Finally, the control variable tested show that the local government type (regency or municipality) influences Local Government's SPIP maturity.

In this research, the SPIP maturity data for all local governments (regency and municipality) in Indonesia cannot be obtained yet. This is because the process of SPIP maturity assessment made by BPKP is still in progress. The researchers also use only data on SPIP guidance in 2014, even though SPIP guidance has been given since the Government Regulation Number 60 Year 2008 was issued. The local expenditure attribute still uses the data on total overall expenditures of local governments, it has not identify in detail the expenditures related to the effort of improving SPIP maturity. Furthermore, this research excludes other attributes which may influence SPIP maturity, such as the role of Government Internal Supervision Officer or Aparat Pengawasan Intern Pemerintah (APIP) and the local head's commitment.

The results of this research show that SPIP guidance frequency has positive influence on Local government's SPIP maturity. To enable the achievement of transparency and accountability goals, local governments ought to pay more attention to improve their SPIP maturity by giving intensive guidance. The regulator, in this case the central government, needs to give a little bit motivation for local governments to be more attentive to their SPIP maturity, in forms of both directives and regulations.

Internal control findings and SPIP maturity are the outcomes of continuous and repeated activities each year, hence it is possible to see what are the perception similarities or differences between SPIP maturity assessment performed by BPKP and SPI audit performed by BPK. The next research can develop this research using such variable as the characteristics of local government inspectorate as the implementation of SPIP including, number and role ranks of local inspectorate auditor, training and development of inspectorate auditors who have possible influence on SPIP maturity. In addition to such factor as the characteristics of internal auditor, the local executive factor such as commitment of local heads as the local executive is also suspected to have some influence on SPIP maturity hence it is possible to add it as an effort of developing this research.

\section{REFERENCES}

Agbejule, A. and A. Jokippi. 2009. Strategy, control activities, monitoring and effectiveness. Managerial Auditing Journal, 24 (6), 500-522.

Andersen, E. S. and S. A. Jessen. 2003. Project maturity in organisations. International journal of project management, 21 (6), 457461.

Arens, A. A., J. K. Randal and S. B. Mark. 2006. Auditing dan jasa assurance: pendekatan integrasi. Jakarta: Erlangga.

Ashbaugh-Skaife, H., W. Daniel and R. K. William. 2007. The discovery and reporting of internal control deficiencies prior to SOX-mandated audits. Journal of Accounting and Economics, 44 (1), 166192.

BPKP. 2009. Keputusan Kepala Badan Pengawasan Keuangan dan Pembangunan Nomor: 1326 tentang Pedoman Teknis Penyelenggaraan Sistem Pengendalian Intern Pemerintah. Jakarta: Badan Pengawasan Keuangan dan Pembangunan.

BPKP. 2016. Keputusan Kepala Badan Pengawasan Keuangan dan Pembangunan Nomor: 4 Tahun 2016 Tentang Pedoman Penilaian dan Strategi Peningkatan Maturitas SPIP. Jakarta: Badan Pengawasan Keuangan dan Pembangunan.

Carey, P. and N. Subramaniam. 2006. Internal audit outsourcing in Australia. Accounting \& Finance, 4 (2), 126-135.

Clements, C., D. N. John and W. Paul. 2015. Multiple directorships, industry relatedness, and corporate governance effectiveness. Corporate Governance, 15 (5), 590-606.

Coram, P., F. Colin and M. Robyn. 2008. Internal audit, alternative internal audit structures and the level of misappropriation of assets fraud. Accounting \& Finance, 48 (4), 543559.

COSO. 2013. Internal control-integrated framework: executive summary. Committee of Sponsoring Organizations of the Treadway Commission.

Doyle, J., G. Weili and M. Sarah. 2007. Determinants of weaknesses in internal control over financial reporting. Journal of accounting and Economics, 44 (1), 193-223.

Halidayati, I. 2014. Pengaruh Pengawasan Internal, Pengawasan Eksternal, dan Implementasi Anggaran Berbasis Kinerja 
Terhadap Kinerja Pemerintah Daerah. Thesis, Universitas Negeri Padang.

Halim, A. and S. Abdullah. 2006. Hubungan dan Maslah Keagenan di pemerintah daerah: (sebuah peluang penelitian anggaran dan akuntansi). Jurnal Akuntansi Pemerintahan, $2(1), 53-64$.

Jensen, J. M. and W. H. Meckling. 1976. Theory of the firm: Managerial behavior, agency costs and ownership structure. Journal of Financial Economics, 3 (4), 305-360

Khlif, H. and K. Samaha. 2016. Audit committee activity and internal control quality in Egypt: does external auditor's size matter?. Managerial Auditing Journal, 31 (3), 269289.

Kumar, N. and K. Kuldip. 2016. Firm size and profitability in Indian automobile industry: An Analysis Pacific Business Review International, 8(7), 69-78

Marfiana, N. and L. Kurniasih. 2013. Pengaruh karakteristik pemerintah daerah dan hasil pemeriksaan audit bpk terhadap kinerja keuangan pemerintah daerah kabupaten/ kota. Sustainable Competitive Advantage, 3 (1).

Minelli, E., R. Gianfranco and T. Matteo. 2009. Why do controls fail? Results of an Italian survey. Critical perspectives on accounting, 20 (8), 933-943.

Peraturan Pemerintah Nomor 60 tahun 2008 tentang Sistem Pengendalian Intern Pemerintah.

Rencana Pembangunan Jangka Menengah Nasional 2015-2019: Buku II. Jakarta.

Sekaran, U. and R. Bougie. 2013. Research methods for business. United Kingdom: Wiley.

Simanjuntak, B. H. 2005. Menyongsong Era Baru Akuntansi Pemerintahan di Indonesia. Jurnal Akuntansi Pemerintah, 1 (1), 9-18.

Suhardjanto, D. and R. R. Yulianingtyas. 2011. Pengaruh karakteristik pemerintah daerah terhadap kepatuhan pengungkapan wajib dalam laporan keuangan pemerintah daerah (studi empiris pada kabupaten/kota di Indonesia). Jurnal Akuntansi \& Auditing, 8 (1), 1-94.

Sutaryo and Jakawinarna. 2013. Karakteristik DPRD dan kinerja penyelenggaraan pemerintah daerah: dukungan empiris dari perspektif teori keagenan. Paper was Presented at Simposium Nasional Akuntansi XVI, Manado.
The Institute of Internal Auditors. 2013. Selecting, using, and creating maturity models: a tool for assurance and consulting engagements.

Undang-UndangU Nomor 1 Tahun 2004 tentang Perbendaharaan Negara.

Xu, X. and L. Gao. 2015. An empirical study on the factors affecting the effectiveness of internal control of listed corporation-based on the perspective of corporate governance. International Journal of Auditing, 12 (4), 45-53.

Zaelani, F. and D. Martani. 2011. The effect of size, growth, and complexity on internal control of local governments. Journal of Creativity and Innovation, 4, 183-206.

Zhang, Y., N. Dongxiao and Z. Hongtao. 2009. Research on the determinants of the quality of internal control: evidence from China. Information Management, Innovation Management and Industrial Engineering Proceeding.

Zhou, H., C. Hanwen and C. Zhirong. 2016. Internal control, corporate life cycle, and firm performance. In The Political Economy of Chinese Finance, 12 (3), 189209. 